\title{
KETERAMPILAN MUSIKALISASI PUISI DENGAN TEKNIK PEMODELAN PADA SISWA KELAS KELAS IX SMP NEGERI 3 RUMBIA KABUPATEN JENEPONTO
}

\author{
RUSNIATI \\ Universitas Muhammadiyah Makassar \\ rusniati@gmail.com
}

\begin{abstract}
Abstrak
Penelitian ini bertujauan meningkatkan hasil belajar siswa dalam bermusikalisasi puisi melalui teknik pemodelan pada siswa kelas Kelas IX SMP Negeri 3 RumbiaKabupaten Jeneponto. Penelitian ini bertujuan untuk melakukan perbaikan yang berdampak pada peningkatan hasil belajar peserta didik. Subjek dalam penelitian ini adalah siswa kelas IX SMP Negeri 3 Rumbia Kabupaten Jeneponto berjumlah 41 siswa, sedangkan obyek penelitiannya adalah keseluruhan proses pembelajaran dengan penerapan teknik pemodelan dalam pembelajaran musikalisasi puisi. Penelitian ini dilaksanakan pada dua siklus yakni siklus I dan siklus II, Indikator keberhasilan penelitian tindakan kelas ini pada aspek proses dan hasil pembelajaran. Teknik pengumpulan data observasi (pengamatan lapangan, catatan lapangan), angket, dokumentasi, tes penampilan (unjuk kerja) dan rekaman. Hasil penelitian siklus 1, dengan jumlah siswa yang memperoleh nilai 80 ke atas sebanyak 11 Orang siswa atau $26,82 \%$. Setelah melihat hasil yang dicapai dengan ketentuan indikator keberhasilan $80 \%$ siswa yang mendapat nilai $\geq 80$, belum mencapai hasil maksimal. Berdasarkanhasilobservasidanevaluasi yang telahdilaksanakanpadasiklus II terjadi peningkatan hasil belajar siswa dalam musikalisasi puisi dengan menggunakan teknik pemodelan dengan perolehan nilai $\geq 80$ berjumlah 39 orang siswa atau $95,12 \%$ dan sedangkan pada siklus II hanya mencapai $26,82 \%$ dengan jumlah siswa sebanyak 11 orang.Dengan demikian dapat disimpulkan bahwa hasil belajar siswa Kelas IX SMP Negeri 3 Rumbia Kabupaten Jeneponto dalam musikalisasi puisi akan meningkat bila menggunakan teknik pemodelan dengan benar.
\end{abstract}

Kata Kunci: Musikalisasi puisi, dan teknik pemodelan

\begin{abstract}
This research aims to improve student learning outcomes in music poetry through modeling techniques in Class IX students of SMP Negeri 3 Rumbia, Jeneponto Regency. This study, is a research that aims to make improvements that have an impact on improving student learning outcomes. The subjects in this study were class IX students of SMP Negeri 3 Rumbia, Jeneponto with a total of 41 students, while the object of the research was the entire learning process by applying modeling techniques in learning musical poetry. This research was conducted in two cycles namely cycle I and cycle II, indicators of the success of this classroom action research on aspects of the process and learning outcomes. Data collection techniques were observations (field observations, field notes), questionnaires, documentation, performance tests (performance) and recordings. The results of the research cycle 1 , with the number of students who score 80 and above as many as 11 students or $26.82 \%$. After seeing the results achieved with the provisions of the indicator of the success of $80 \%$ of students who scored $\geq 80$, not yet reached the maximum results. Based on the results of observations and evaluations that have been carried out in the second cycle there was an increase in student
\end{abstract}


learning outcomes in musical poetry using modeling techniques with the value of $\geq 80$ totaling 39 students or $95.12 \%$ and whereas in the second cycle it only reached $26.82 \%$ with the number 11 students. Thus, it can be concluded that the learning outcomes of Class IX students of SMP Negeri 3 Rumbia, Jeneponto Regency in musical poetry will increase when using modeling techniques correctly.

Keywords: Musicalisation of poetry, and modeling techniques

\section{PENDAHULUAN}

Pengajaran sastra merupakan bagian dari isi kurikulum pengajaran Bahasa dan Sastra Indonesia berfungsi untuk mengembangkan kemampuan menikmati, menghayati, memahami, memanfaatkan karya serta untuk pengembangan kepribadian, pengetahuan, dan kemampuan berbahasa. Kemampuan mengapresiasi karya sastra secara kreatif diharapkan dapat mendorong keberanian siswa untuk menuangkan pengalaman, gagasan, dan perasaannya dalam berbagai bentuk karya sastra seperti puisi, prosa dan drama. Tujuan pembelajaran sastra yang ditetapkan akan sejalan dengan pandangan terhadap bahwa sastra adalah dulce et utile, yakni sesuatu yang indah dan bermakna. ${ }^{1}$

Tujuan pengajaran bahasa dan sastra Indonesia di sekolah dimaksudkan untuk menumbuhkan keterampilan, rasa cinta, dan penghargaan para siswa terhadap bahasa dan sastra Indonesia sebagai bagian dari budaya warisan leluhur. Dengan demikian, tugas guru bahasa dan sastra Indonesia tidak hanya memberi pengetahuan saja, tetapi juga keterampilan dan menanamkan rasa cinta, baik melalui kegiatan di dalam kelas ataupun di luar kelas.

Puisi secara harfiah dapat diartikan sebagai ungkapan batin seorang penyair melalui katakata yang dituangkan ke dalam tulisan dengan gaya dan ungkapan tertentu.Puisi sebagai bagian dari karya sastra, tentunya banyak mengandung nilai dan keindahan khas yang akan terungkap jika kita mampu memahaminya dengan baik dan benar. Pendapat tersebut seakan menegaskan bahwa puisi merupakan karya sastra yang mengandung kata kias imajinatif yang harus dikenali maknanya dengan segala keindahan yang terkandung di dalamnya, selain unsur-unsur lainnya yang membuat puisi menjadi karya sastra yang kaya dengan etika dan estetika.

Musikalisasi puisi merupakan proses mengubah puisi menjadi sebuah lagu, dan menjadikan puisi dalam bentuk musik yang sesuai dengan jiwa puisi dengan demikian antara musik dan puisi haruslah memiliki kesatuan dan keselarasan, sehingga apa yang

\footnotetext{
${ }^{1}$ Esti Ismawati, Pengajaran Sastra (Yogyakarta: Penerbit Ombak, 2013), h. 3.
} 
terkandung dalam puisi tetap utuh, namun dalam mengubah puisi menjadi sebuah musik harus memperhatikan suasana yang terkandung dalam puisi tersebut. Musikalisasi puisi merupakan materi pelajaran baru yang terdapat dalam silabus SMA Wajib kurikulum 2013 versi 2016. Sebelumnya musikalisasi puisi hanya dilakukan dalam kegiatan ekstrakurikuler di sekolah.

Hal yang penting dalam musikalisasi puisi adalah kepekaan rasa sehingga dapat menyesuaikan karakter musik yang dipilih sebagai lirik lagunya sehingga suasana dan pesan yang terkandung dalam puisi dapat dengan mudah disampaikan pada pendengar. Dalam musikalisasi puisi, aransemen musik tidak boleh mengubah jiwa puisi dan makna puisi harus tetaputuh. Musikalisasi puisi adalah suatu kegiatan penciptaan musik berdasarkan sebuah puisi sehingga pesan yang ada dalam puisi semakin jelas maknanya.Selain itu, pengertian musikalisasi puisi adalah puisi yang dilagukan, sedangkan aransemen musik pengiringnya adalah sebuah upaya untuk menambahkan cita rasa yang mempertegas makna dari pemahaman puisi yang dilagukan itu.

Ada 3 batasan yang harus dipenuhi sehingga sebuah karya dapat dikategorikan sebagai musikalisasi puisi, yaitu 1) puisi yang dimusikalisasikan dapat dipertanggungjawabkan keotentikannya dan sesuai dengan kaidah-kaidah yang ada dalam ilmu kesusastraan; 2) lagu atau komposisi nada yang tercipta harus orisinil, tidak menjiplak atau menggunakan komposisi yang sudah pernah ada; 3) proses kreatif yang berurutan. Selain itu dalam memusikalisasikan puisi harus ada puisinya terlebih dahulu lalu dibuat komposisi nada/lagu yang sesuai dengan interpretasi dari puisi itu tanpa mengubah susunan kata yang ada dalam puisi. Jadi, komposisi nada yang menyesuaikan dengan puisi. Proses kreatif ini tidak dapat dibalik. Tidaklah termasuk musikalisasi puisi apabila terlebih dahulu dibuat lagunya baru dimasukkan puisi yang menyesuaikan dengan lagu, atau jika puisi dan lagu dibuat secarabersamaan.

Indikator dalam penilaian musikalisasi puisi yaitu interpretasi/memahami isi puisi, vokal yang terdiri atas lafal dan intonasi, komposisi musikal, keselarasan yang terdiri dari harmonisasi dan koherensi, penampilan yang terdiri dari sikap dan kreativitas. Pada pengajaran puisi dan musikalisasi puisi kita mengenal istilah apresiasi. Apresiasi adalah kegiatan menggauli karya sastra secara sungguh-sungguh sehingga menumbuhkan pengertian, penghargaan, kepekaan pikiran kritis, dan kepekaan perasaan yang baik terhadap karya sastra.

Teknik pemodelan selain guru secara langsung menjadi model, dapat juga 
menggunakan model (contoh) siswa yang berprestasi dalam bidang musikalisasi puisi, sehingga siswa yang akan belajar musikalisasi puisi bisa meniru contoh musikalisasi puisi yang baik, sehingga siswa yang sedang belajar membuat musikalisasi puisi mampu membangun pengetahuan yang diperolehnya dari model (contoh) untuk dapat memusikalisasikan puisi dengan baik. Selain itu, teknik pemodelan juga dapat membantu mengatasi keterbatasan yang dimiliki olehguru.

Berdasarkan uraian di atas, pelajaran musikalisasi puisi sangat penting diajarkan dan dikuasai oleh siswa sebab dengan belajar memusikalisasikan puisi secara bersungguhsungguh siswa akan memeroleh 1) pengetahuan, pemahaman, pengalaman batin melalui kegiatan yang dilakukan pada tahap apresiasi yaitu menganalisis puisi untuk menemukan unsur-unsur pembangun puisi, menafsirkan puisi sehingga dapat menemukan makna dan maksud yang tertuang dalam puisi selanjutnya siswa mampu mengkreasikan puisi ke dalam bentuk lain yaitu memusikalisasikan puisi sehingga makna yang terdapat di dalam puisi lebih jelas; 2) Kegiatan memusikalisasikan puisi dilakukan secara berkelompok, dengan demikian secara tidak langsung terjalin kerjasama antarindividu dalam kelompok dan memunculkan rasa tanggung jawab bersama untuk membuat rasa dalam puisi yang diwujudkan dalam nada dan irama menjadi lebih indah, harmonis, namun makna puisi tetap utuh sesuai dengan suasana yang melatarbelakangi puisi; 3) melalui kegiatan musikalisasi puisi, diharapkan akan tumbuh sikap intelektual siswa yang dituangkan dalam ide, gagasan, kreativitas yang tergambar dalam mengekspresikan puisi yang dimusikalisasi, matang secara pribadi untuk mengembangkan sikap sosial dan menjadi lebih maju secara emosional; 4) menumbuhkan kepekaan rasa, rasa cinta dan penghargaan yang tinggi terhadap karya-karya sastra, khususnya puisi.

Berdasarkan temuan permasalahan yang dikemukakan di atas, penulis ingin mendeskripsikan proses dan peningkatan hasil belajar siswa pada materi musikalisasi puisi melalui teknik pemodelan. Selanjutnya, peneliti berharap dalam perkembangannya ke depan terjadi pergeseran peran guru dari pengajar menjadi fasilitator yang mampu

membimbing, membangkitkan, dan mengarahkan siswa kepada aktivitas dan pengoptimalan kemampuan diri.

\section{KAJIAN PUSTAKA}

\section{Musikalisasi Puisi}

Musikalisasi puisi dapat didefinisikan sebagai sarana mengomunikasikan puisi 
kepada apresian, melalui persembahan musik (nada, irama, lagu, atau nyanyian). Musikalisasi puisi merupakan upaya memusikkan puisi atau menggabungkan antara seni baca puisi dan seni musik. Materi dasar seni baca puisi adalah puisi itu sendiri, sedangkan materi dasar seni musik adalah lagu dan instrumen. ${ }^{2}$

Musikalisasi puisi adalah upaya untuk menyampaikan pesan-pesan puisi kepada audiens melalui musik. Definisi ini dapat diartikan sebagai "cara-cara tertentu yang bersifat kreatif untuk menafsirkan, membacakan, melisankan, menyuarakan teks dan makna puisi kepada audiens dengan menggunakan unsur-unsur musik, instrumen atau alat-alat musik, atau komposisi dan aransemen musik". 3

Menyampaikan pesan puisi melalui musik berarti di dalamnya terkandung adanya proses "transformasi" atau proses alih ragam, alih bentuk, alih jenis, yang dalam teori seni disebut alih wahana. Namun demikian, hal ini juga terkadang masih disalah pahami oleh beberapa orang, bahkan oleh penyair itu sendiri. Mungkin karena keterbatasan informasi, atau kurang memahami makna "transformasi", kata "perubahan" masih diartikan atau dipersamakan dengan "mengubah teks puisi”, dan bukan "beralihnya wahana puisi”.

Musikalisasi puisi dapat dikatakan sebagai bentuk memusikkan atau melagukan puisi. ${ }^{4}$ Selanjutnya, Danardana mengemukakan pendapatnya sebagai berikut. Musikalisasi puisi pada hakikatnya adalah kolaborasi apresiasi seni, antara musik, puisi, dan pentas. Melalui musikalisasi puisi, seseorang tidak hanya mendapat kesempatan mengapresiasi puisi dan musik, tetapi juga mendapat kesempatan mengekspresikan apresiasinya itu di depan khalayak. ${ }^{5}$

Komunikasi yang terbangun sebagai sarana dari penyampaian ini. Pada musikalisasi puisi tentunya tidak sekadar bentuk penampilan musik saja, karena musik ini dapat diciptakan tentunya setelah pemusikalisasi sudah sangat memahami, mengerti, dan menghayati isi dari puisi, sehingga segala penafsirannya pada puisi tersebut bisa ia lahirkan lewat aransemen musik. Tentulah hasil yang diperoleh pun akan merupakan suatu karya yang utuh, menyatu (musik dengan puisi) dan bukan karya sendiri-sendiri.

Mengacu pada hal tersebut, dan juga pada keberagaman jenis musikalisasi puisi yang berkembang, pengertian musikalisasi puisi dapat didefinisikan sebagai sarana

\footnotetext{
${ }^{2}$ KPIN Ari, Musikalisasi Puisi: Tuntunan dan Pembelajaran (Yogyakarta: Hikayat, 2008), h. 9.

${ }^{3}$ Hamdy Salad, Panduan Wacana \& Apresiasi Musikalisasi Puisi (Yogyakarta: Pustaka Pelajar, 2015), h. 164.

${ }^{4}$ Mukh Doyin, Seni Baca Puisi (Persiapan, Pelatihan, dan Pementasan, dan Penilaian) (Semarang: Bandungan Institute, 2008), h. 4.

${ }_{5}^{5}$ A. S. Danardana, Pelangi Sastra: Ulasan dan Model-Model Apresiasi (Pekanbaru: Palagan Press, 2013), h. 56.
} 
mengomunikasikan puisi kepada apresian melalui persembahan musik (nada, irama, lagu, ataunyanyian).

Pada praktiknya, kegiatan menyanyikan puisi ini lebih menarik diterapkan pada sekolah-sekolah dimulai sekolah lanjutan pertama sampai tingkat mahasiswa. Kegiatan musikalisasi puisi jenis ini ternyata diminati mereka yang ingin menggunakan cara lain dari sekadar membaca puisi.

Berdasarkan paparan dan ulasan tentang definisi puisi di atas, ada tiga unsur pokok yang perlu dipahami secara utuh, yaitu: kedudukan puisi sebagai teks sastra, alih wahana puisi ke dalam seni musik, serta unsur-unsur estetik musikalisasi puisi.

Berikut Bagan 2.1 Skema transformasi puisi menjadi musikalisasi puisi

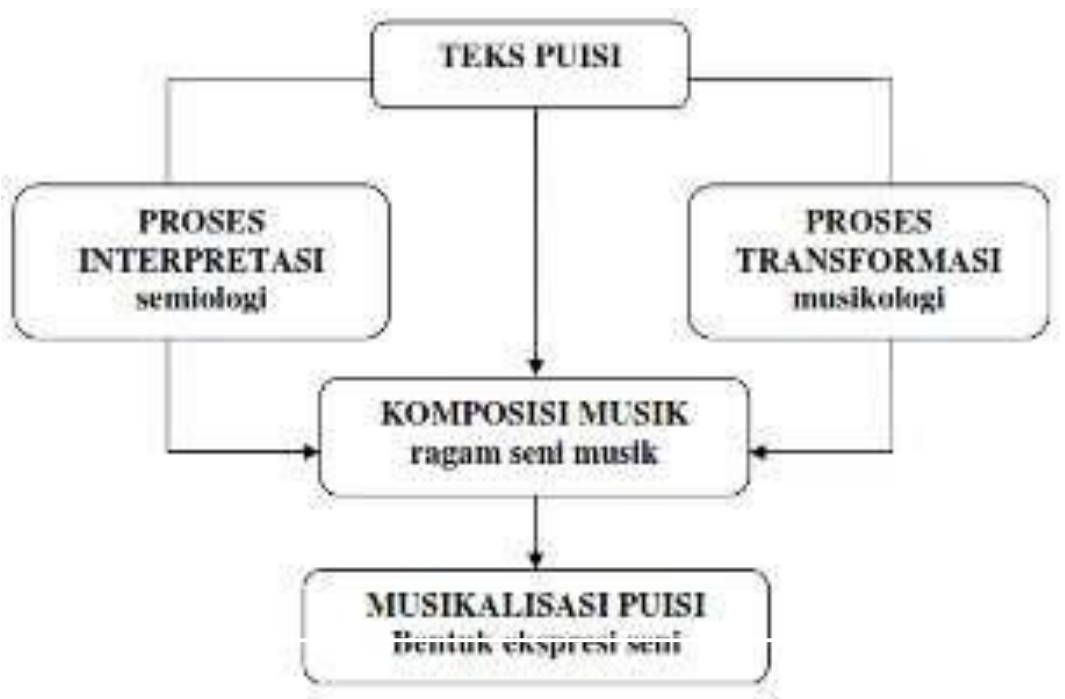

Bagan 1 Skema Transformasi Puisi Menjadi Musikalisasi Puisi

Tahap Pelaksanaan

Tahap ini terdiri atas beberapa langkah:

> Guru menyajikan musikalisasi puisi dari media yang telah dipersiapkan. Siswa menyimak musikalisasi puisi tersebut sambil memperhatikan pula tiap kata dalam teks puisi. Penyajian diulang hingga dua kali;

$>$ Guru bertanya jawab dengan siswa tentang kesan-kesan siswa setelah menyimak musikalisasi puisi tadi, perasaan siswa, imajinasi siswa, dan keterlibatan jiwa terhadap puisiitu;

$>$ Guru bertanya jawab dengan siswa tentang pokok pembicaraan yang disampaikan penyair dalam puisi itu, nada penyair, dan maksud penyair dalam puisiitu; 
$>$ Guru mengajak siswa mengkaji puisi itu dengan mempertahankan unsurunsur puisi, seperti diksi, majas, pencitraan, bunyi, tifografi, dan lain- lain, hingga diperoleh penafsiran tentang maknapuisi;

$>$ Guru bertanya jawab dengan siswa tentang kaitan (relevansi) puisi tersebut dengan pengalaman dan kehidupan siswa, dan kebermaknaan puisi itu bagi siswa

Tahap Pengukuhan

Tahap ini dilakukan untuk memperkuat daya apresiasi siswa terhadap puisi itu. Pengukuhan dapat dilakukan secara tertulis atau lisan. Secara tertulis siswa dapat diminta untuk membuat parafrase puisi tersebut. Secara lisan, siswa dapat diminta untuk membacakan puisi itu di depankelas.

Membuat Musikalisasi Puisi

Kajian tentang membuat musikalisasi puisi ini penulis rangkum dari Ari KPIN, yang menjabarkan musik memiliki karakteristik tersendiri. Puisi pun demikian. Dalam musikalisasi puisi, musik dan puisi ini dipadukan untuk menyampaikan atau mengomunikasikan makna puisi. Agar dapat melakukannya dengan baik, tentulah harus dikuasai teknik-tekniknya. Selain itu, karena ada dua unsur yang disatukan di dalamnya, yaitu musik dan puisi, kedua hal ini pun harus dikuasai terlebih dahulu. ${ }^{6}$

\section{Aspek-Aspek Cara Membuat Musikalisasi Puisi SecaraTepat}

\section{Pemusikalisasi Puisi}

Ada dua hal yang harus diperhatikan oleh seseorang yang ingin membuat musikalisasi puisi. Pertama berhubungan dengan musik, dan yang kedua berhubungan dengan puisi.

Dalam kaitannya dengan hal pertama, si pemusikalisasi puisi harus sudah mempunyai kemampuan teknis dalam bidang musik. Artinya, dia harus tidak punya kendala teknis dalam bidangnya sendiri (musik). Adapun berhubungan dengan hal kedua, seseorang yang akan memusikalisasi puisi hendaknya sudah memiliki bekal sejumlah pengertian yang berhubungan dengan puisi itu sendiri. Juga kemampuan teknis dalam membaca (memahami, menikmati, dan memasuki unsur-unsur puisi secara lebih mendalam).

\section{Menyampaikan Puisi melalui Musik}

Penyair berusaha mengolah dan menggali daya tarik dan daya ungkap bahasa dalam puisinya yang berupa bunyi, rima dan irama, . segala aspek puisi itu hendaknya dapat

\footnotetext{
${ }^{6}$ KPIN Ari, Musikalisasi Puisi: Tuntunan dan Pembelajaran, h. 17-54.
} 
ditangkap oleh seorang pemusikalisasipuisi.

Dengan mengkaji dan menangkap aspek-aspek tersebut, arti puisi pun dapat tertangkap, baik arti berupa pokok pembicaraan dalam puisi, perasaan dan suasana hati yang terkandung dalam puisi, nada bicara penyair dalam mengungkapkan puisi, dan maksud atau tujuan yang ingin dicapai penyair dalam puisiitu.Keempatartitersebuthendaknyadapattertampilkanatauterpresentasikan dalam karya musikalisasi puisi. Artinya, puisi tidak sekadar memberi warna musik atau irama pada puisi, tapi juga menampilkan ruh puisi yang hendaknya dapat membangkitkan daya tarik, daya ungkap, dan daya sentuh puisi yangdigarap.

\section{Penggunaan Alat Musik untuk MusikalisasiPuisi}

Selama ini ada semacam salah tafsir terhadap apa yang dinamakan musikalisasi puisi. Seperti pernah diungkapkan Putu Fajar Arcana (kompas, 2004), selama ini musikalisasi puisi cenderung diidentikkan dengan minimalitas penggunaan alat musik. Banyak yang kemudian beranggapan musikalisasi puisi harus bernuansa sendu dansunyi.

Persoalan kejernihan sebuah musikalisasi puisi, tidak terletak pada penggunaan alat musiknya, tapi pada keberhasilan pemusikalisasimenerjemahkan tafsiran puisi ke dalam karya musiknya, sehingga makna puisi itu terkomunikasikan dengan baik kepadaapresian. Puisi yang mengandung perasaan riang, ceria, misalnya tentunya menghendaki irama-irama yang riang dan ceria pula, dengan penggunaan alat-alat musikyangbisamengeluarkanbunyibunyidannada-nadariang,sertapenampilan yang riang pula daripenampilan. Puisi yang berisi tentang kekerasan tentunya membutuhkan instrumen- instrumen musik yang bisa menerjemahkan kekerasan itu. Setiap jenis puisi memerlukan pemusikalisasian yang berbeda pula.Tidak selalu harus dalam nuansa sendu.

\section{METODE PENELITIAN}

Penelitian ini, adalah Penelitian Tindakan Kelas (PTK) yang bertujuan untuk melakukanperbaikanyangberdampakpadapeningkatanhasilbelajarpesertadidik. Menurut Penelitian Tindakan Kelas dapat dipahami pengertiannya sebagai berikut, penelitian adalah kegiatan mencermati suatu objek, menggunakan aturan metodelogi tertentu untuk memperoleh data/informasi yang bermanfaat untuk meningkatkan mutu suatu hal yang menarik minat dan penting bagipeneliti. ${ }^{7}$

Lokasi penelitian di sekolah SMP Negeri 13 Rumbia Kabupaten Jeneponto Penelitian

\footnotetext{
${ }^{7}$ Arikunto, Prosedur Penelitian Suatu Pendekatan Praktek (Jakarta : PT. Rineka Cipta, 2006), h. 89.
} 
ini dilaksanakan pada semester genap Tahun Pelajaran 2017/2018. Pelaksanaan PTK sesuai dengan jadwal pelajaran dan penelitian ini berlangsung sampai indikator yang telah ditentukan sekolah tercapai yakni kriteria ketuntasan belajar 71 atau indikator pencapaian ketuntasan $80 \%$.

Teknik pengumpulan data dalam penelitian dikumpulkan meliputi data kualitatif dan data kuantitatif. Data kualitatif berkaitan dengan proses pembelajaran, sementara data kuantitatif berkaitan dengan hasil latihan siswa. Instrumen yang digunakan untuk mengumpulkan data berupa lembar penilaian formatif, kerja kelompok, dan lembar observasi. Data kuantitatif akan diolah melalui analisis deskriptif, sedangkan data kualitatif akan diolah dalam bentuk paparan narasi yang menggambarkan kualitas pembelajaran yang dilakukan dengan observasi (pengamatan lapangan, catatan lapangan), angket, dokumentasi, tes penampilan (unjuk kerja) dan rekaman. Teknik observasi dilakukan dalam pengumpulan data. Observasi/pengamatan merupakan kegiatan pemusatan perhatian terhadap suatu objek dengan menggunakan seluruh indera. Teknik ini dilakukan untuk melihat semua aktivitas guru dan siswa dalam kegiatan pembelajaran. Teknik observasi ini menggunakan instruemn pedoman observasi yang berisi butir-butir kegiatan yang diamati terhadap aktivitas yang diteliti melalui teknik pemodelan selama kegiatan pembelajaran berlangsung.

Observasi diartikan sebagai pengamatan dan pencatatan secara sistematik terhadap gejala yang tampak pada objek penelitian (Margono, 2007: 158). Observasi dilakukan oleh peneliti selama proses pembelajaran berlangsung. Observasi yang dilakukan dalam penelitian ini antara lain konsistensi RPP dengan pelaksanaan pembelajaran, misalnya cara guru mengajarkan materi, cara guru menggunakan media pembelajaran, cara guru menjelaskan tujuan pembelajaran dan bagaimana menggunakan media musikalisasi, serta cara guru memberikan penilaian.

Di samping itu, observasi juga dilakukan pada siswa antara lain yaitu keaktifan siswa dalam menggunakan teknik pembelajaran musikalisasi, perubahan prestasi belajar dari siklus I ke siklus II.

\section{HASIL PENELITIAN DAN PEMBAHASAN}

\section{Data Proses Siklus 1}

Pada tahap perencanaan, peneliti dan guru kelas IX secara kolaboratif menentukan hal-hal yang perlu dilakukan dalam pelaksanaan kegiatan pembelajaran dalam hal ini musikalisasi puisi melalui teknik pemodelan sebagai media pembelajaran yang digunakan 
peneliti dalam musikalisasi puisi dengan menggunakan teknik pemodelan. Dari hasil diskusi antara peneliti dan guru Kelas IX SMP Negeri 3 Rumbia Kabupaten Jeneponto menetapkan beberapa hal yang perlu dilakukan, antara lain:

a) Menentukan langkah-langkah KBM yang akan dilaksanakan pada tahap siklus 1 .

b) Menyiapkan tugas musikalisasi puisi yang digunakan sebagai media dalam pembelajaran melalui teknik pemodelan

c) Menyusun rambu-rambu instrumen data keberhasilan guru maupun instrumen data keberhasilan siswa, berupa format observasi, tes, dan persiapan rekaman kegiatan tindakan berupa foto pelaksanaan tindakan.

Tahap pelaksanaan tindakan, pelaksanaan pembelajaran musikalisasi pada mata pelajaran bahasa Indonesia KelasIXSMPNegeri3RumbiaKabupaten Jeneponto, dalam pelaksanaan pembelajaran di lakukan oleh peneliti dan guru bertindak sebagai pengamat.

Kegiatan awal pelaksanaan pembelajaran peneliti terlebih dahulu mengkondisikan siswa pada saat situasi belajar yang kondusif dan selanjutnya peneliti melakukan persiapan pembelajaran dengan menyiapkan alat dan bahan yang akan digunakan. Pada tahap selanjutnya guru melaksanakan apersepsi sebelum memulai inti dari pembelajaran dengan mengadakan tanya jawab kepada siswa tentang pengalaman sehari-hari mereka untuk mengaitkan dengan materi yang akan diajarkan.

Proses kegiatan awal pembelajaran berlangsung pengamat (guru) sudah mulai mengamati setiap pelaksanaan kegiatan yang dilakukan oleh peneliti dan siswa dengan mengisi lembaran format observasi yang telah disediakan sebelumnya untuk mengetahui hasil pelaksanaan dari setiap kegiatan dan tindakan yang diberikan oleh peneliti selama proses pembelajaran berlangsung.

Kegiatan selanjutnya adalah inti dari pelaksanaan pembelajaran, dimana peneliti menjelaskan materi pembelajaran yang akan dilaksanakan yakni musikalisasi puisi dengan menggunakan teknik pemodelan. Dalam menyampaikan materi pembelajaran peneliti mengarahkan siswa untuk memperhatikan dengan baik penjelasan yang di sampaikan oleh peneliti tentang bagaimana memusikalisasi puisi yang baik dengan menggunakan teknik pemodelaln mulai dari cara mengubah puisi kedalam bentuk lagu, pemilihan kata-kata yang tepat, penggunaan tanda baca, dan sebagainya.

Setelah peneliti menjelaskan materi pembelajaran musikalisasi puisi siswa diberi kesempatan untuk mengajukan pertanyaan tentang materi yang belum dipahami sebelum siswa ditugaskan untuk menentukan tema/topik. 
Tahap selanjutnya adalah observasi dan evaluasi. Tahap observasi siklus 1 yang dilakukan dengan cara mengamati bagaimana guru menyajikan materi pembelajaran tentang musikalisasi dengan menggunakan teknik pemodelan apakah sudah sesuai dengan rencana pelaksanaan pembelajaran atau belum sesuai sama sekali, dan disamping itu juga melihat bagaimana aktivitas yang dilakukan siswa selama proses pembelajaran berlangsung.

Berdasarkan hasil observasi yang dilakukan guru yang bertindak sebagai observer dalam pembelajaran musikalisasi puisi dengan menggunakan teknik pemodelan pada mata pelajaran bahasa Indonesia menunjukan bahwa masih kurangnya kemampuan peneliti dalam menguasai kelas dan mengatasi setiap permasalahan-permasalahan yang muncul dari siswa, peneliti tidak menyampaikan tujuan pembelajaran musikalisasi puisi dengan menggunakan teknik pemodelan, peneliti masih kurang dalam memotivasi dan mengarahkan siswa untuk dapat belajar dengan baik, peneliti kurang merespon secara keseluruhan setiap pertanyaan yang diajukan siswa, dalam penjelasan materi dengan menggunakan teknik pemodelan, belum terlaksana dengan baik sehingga siswa kurang mampu memahami penjelasan yang disampaikan peneliti tentang bagaimana musikalisasi puisi dengan menggunakan teknik pemodelan, peneliti kurang maksimal dalam memantau setiap aktivitas yang dilakukan oleh siswa dan memberikan bimbingan terhadap siswa yang mendapat masalah dalam musikalisasi puisi dengan menggunakan teknik pemodelan.

Hasil observasi yang dilakukan terhadap siswa menunjukkan bahwa siswa kurang aktif secara langsung memperhatikan penjelasan materi yang disampaikan oleh peneliti, siswa kurang dapat memahami dengan cepat maksud dari setiap penjelasan materi yang disampaikan oleh peneliti, siswa masih kurang berani untuk mengajukan pertanyaan tentang materi yang belum dipahami saat peneliti menjelaskan, dan siswa masih kurang mampu mengubah puisi dalam bentuk lagu.

Tahap selanjutnya adalah refleksi. Dalam melakukan refleksi, berdasarkan hasil observasi dan evaluasi pada pelaksanaan tindakan siklus 1, belum mencapai indikator keberhasilan yang telah ditetapkan yakni $85 \%$ yang mendapatkan nilai $\geq 80$, dimana dalam pelaksanaan tindakan siklus 1 masih terdapat kelemahan-kelemahan dan kekurangan dalam pelaksanaan pembelajaran dari awal sampai akhir pelaksanaan pembelajaran.

Hasil pengamatan yang telah dilakukan untuk mengetahui letak ketidak berhasilan yang dicapai pada pelaksanaan siklus 1 adalah dari guru dan siswa itu sendiri, peneliti tidak menyampaikan tujuan pembelajaran agar pelaksanaannya lebih terarah serta kurangnya kemampuan peneliti dalam memberikan motivasi, bimbing dan menanggapi setiap permasalahan yang muncul dari siswa. 
Permasalahan yang timbul dari siswa sehingga tidak mencapai keberhasilan pada tahap pelaksanaan siklus 1 adalah sebagai berikut:

a) Masih terdapat beberapa orang siswa yang kurang aktif memperhatikan penjelasan yang disampaikan oleh peneliti selama proses pembelajaran musikalisasi puisi dengan menggunakan teknik pemodelan berlangsung.

b) Kurangnya keberanian yang dimiliki oleh siswa untuk mengajukan dan menanggapi setiap pertanyaan yang diajukan peneliti tentang materi yang belum dipahami.

c) Kurangnya kemampuan siswa dalam memahami dan merespon setiap penjelasan yang disampaikan oleh peneliti.

d) Masih terdapat beberapa orang siswa yang masih sulit untuk memilih dan menentukan tema/topik yang tepat berdasarkan gambar seri, serta siswa masih sulit untuk memilih dan menggunakan kata-kata yang tepat dalam merangkai sebuah kalimat.

Agar tahap pelaksanaan selanjutnya pada siklus II lebih baik dan terarah, peneliti dan guru mendiskusikan hal-hal yang perlu ditingkatkan dan disempurnakan agar tercapai indikator keberhasilan dalam pembelajaran musikalisasi puisi dengan menggunakan teknik pemodelan.adalah sebagai berikut:

a) Mengkondisikan kelas dengan suasana yang kondusif dan menyenangkan serta menanggapi setiap permasalahan yang muncul dari siswa yang dapat menimbulkan gangguan belajar.

b) Menyampaikan tujuan pembelajaran yang hendak dicapai siswa.

c) Memberikan bimbingan kepada siswa agar lebih termotivasi untuk lebih giat dan aktif dalam pembelajaran.

d) Membangkitkan semangat gairah belajar siswa dengan memberikan dukungan moril dari dalam diri siswa.

e) Memberikan stimulus kepada siswa agar termotivasi untuk berani mengajukan pertanyaan.

f) Menuntun siswa yang mengalami kesulitan belajar dalam menulis sebuah karangan.

\section{KESIMPULAN}

Berdasarkan data proses dan hasil serta pembahasannya pada tiap siklus diperoleh tingkat keberhasilan penelitian sebagai berikut : (1) Preose teknik pemodelan terhadap musikalisasi puisi sangat efekti digunakan di sekolah , (2) Pada siklus I peneliti belum mencapai keberhasilan ini ditandai dengan perolehan hasil tes yang hanya mencapai $26,82 \%$ dan belum memenuhi standar indikator keberhasilan penelitian hal ini disebabkan karena 
salah satunya adalah kurangnya keaktifan siswa dalam mengikuti pembelajaran. (3) Pada siklus II penelitian tersebut telah berhasil ditingkatkan, hal ini bisa dilihat pada peningkatan proses hasil pembelajaran yang di tunjukkan oleh guru dan siswa.

Proses pelaksanaannya guru (peneliti) telah mampu meningkatkan kualitas pembelajaran dengan mengarahkan dan membimbing siswa serta memberikan motivasi secara maksimal dalam proses pembelajaran musikalisasi puisi, dan disamping itu juga keseriusan dan keaktifan siswa serta timbulnya keberanian untuk bertanya tentang materi yang belum dipahami yang ditunjukkan oleh siswa dari awal sampai akhir proses berjalannya pembelajaran musikalisasi puisi dengan menggunakan teknik pemodelan. Dengan demikian dapat disimpulkan bahwa hasil belajar siswa Kelas IX SMP Negeri 3 Rumbia Kabupaten Jeneponto dalam musikalisasi puisi akan meningkat bila menggunakan teknik pemodelan dengan benar.

\section{DAFTAR PUSTAKA}

Ismati, Esti. (2013). Pengajaran Sastra. Yogyakarta: Penerbit Ombak.

Ari, KPIN. (2008). Musikalisasi Puisi: Tuntunan dan Pembelajaran.Yogyakarta: Hikayat.

Salad, Hamdy.Panduan Wacana \& Apresiasi Musikalisasi Puisi. Yogyakarta: Pustaka Pelajar, 2015.

Arikunto.Prosedur Penelitian Suatu Pendekatan Praktek.Jakarta: PT. Rineka Cipta, 2006.

Triyono. (2012). Metodelogi Penelitian Pendidikan.Yokyakarta: Ombak.

Suharianto,S. (1981). Pengantar Apresiasi Puisi. Surakarta:Widya Duta.

Sugiyono. (2011). Metode Penelitian Kuantitatif, Kualitatif, dan $R \& D$. Bandung: Alfabeta.

Permendikbud. 2014. Nomor 103 Tahun 2014 Tentang Pembelajaran pada Pendidikan Dasar dan Pendidikan Menengah. 